\title{
Time Economic Innovative Methodology on the Prediction of Hybridization State of Heterocyclic Compounds
}

\author{
Arijit Das $^{1^{*}}$, Bijaya Paul ${ }^{2}$, R.Sanjeev ${ }^{3}$ and V.Jagannadham ${ }^{4}$ \\ ${ }^{I}$ Department of Chemistry, Ramthakur College, Agartala -799003, Tripura, India \\ ${ }^{2}$ Department of School Education, Agartala, West Tripura, India \\ ${ }^{3}$ Department of Pharmacy, School of Health Science, University of KwaZulu-Natal, Durban, South Africa \\ ${ }^{4}$ Department of Chemistry, Osmania University, Hyderabad, India
}

Abstract: Context based learning approaches have been presented in this article as a way to enhance student's interest in, as well as time economic learning outcomes from chemical education. In this article state of $s-p$ hybridization of hetero atoms in heterocyclic compounds is empirically calculate from the number of bonds and delocalized lone pair of electrons associated with it. The article explores the results and gives implications for context-based teaching, learning and assessment.

Keywords: General public, High School, Under Graduate, Graduate student, Chemical Education Research, Organic Chemistry, Hybridization, Heterocyclic Compounds and Chemical Bonding

\section{Introduction}

Earlier I have introduced some methods ${ }^{1,2,3}$ in my original research article and also in review article mode for prediction of hybridization state of different kinds of Organic and Inorganic molecules and ions on conventional method $\mathrm{d}^{4,5,6,7,8}$ by calculating the number of sigma bonds around each center atom for which hybridization state should be determined. But there is some limitation arises during prediction of hybridization state in case of heterocyclic compounds like Pyrrole, Furan, Thiophene etc. For this reason, in this article, I have introduced another innovative time economic method for the Prediction of Hybridization state in case of heterocyclic compounds.

\section{Innovative Methodology on the Prediction of Hybridization state of Hetero atom in Heterocyclic} Compounds:

Total power on Hybridization State $(X)=$ TNBS + DLP

Where, TNBS $=$ Total Number of bonds directly attached with hetero atom excluding $\mathrm{H}$ bond if any attached with hetero atom

DLP $=$ Delocalized lone pair electrons through resonance

- For $\mathrm{sp}$; Power on $\mathrm{s}=1$ and Power on $\mathrm{p}=1$, Hence Total power $=(1+1)=2$

- For $\mathrm{sp}^{2}$; Power on $\mathrm{s}=1$ and Power on $\mathrm{p}=2$, Hence Total power $=3=(1+2)=3$

- For $\mathrm{sp}^{3} ;$ Power on $\mathrm{s}=1$ and Power on $\mathrm{p}=3$, Hence Total power $=(1+3)=4$

Examples have been illustrated in Table-1

\begin{tabular}{|c|c|c|c|c|}
\hline \multicolumn{5}{|c|}{$\begin{array}{l}\text { Examples have been illustrated in Table-1 } \\
\text { Table-1 }\end{array}$} \\
\hline Heterocyclic Compounds & $\begin{array}{c}\text { TNBS } \\
\text { ( Total number of bonds around } \\
\text { hetero atom } \\
\text { excluding H Bond) } \\
\end{array}$ & $\begin{array}{c}\text { DLP } \\
\text { (Delocalized Lone } \\
\text { Pair of es } \mathrm{e}^{-\mathrm{s}} \text { ) }\end{array}$ & $\begin{array}{c}\text { Total Power }(X)= \\
\text { TNBS + DLP }\end{array}$ & Hybridization State \\
\hline & 2 & 1 & 3 & $\mathrm{sp}^{2}$ \\
\hline & 2 & $\begin{array}{c}1 \\
\text { (out of two lone pair } \\
\text { of electrons, one can } \\
\text { take part in } \\
\text { delocalization at a } \\
\text { time) }\end{array}$ & 3 & $\mathrm{sp}^{2}$ \\
\hline
\end{tabular}


Time Economic Innovative Methodology on the Prediction of Hybridization State of ....

\begin{tabular}{|l|c|c|c|}
\hline & $\begin{array}{r}1 \\
\text { (out of two lone pair } \\
\text { of electrons, one can } \\
\text { take part in } \\
\text { delocalization at a } \\
\text { time) }\end{array}$ & sp $^{2}$ \\
\hline
\end{tabular}

\section{Conclusions}

It may be expected that this innovative method would go a long way to help to the students of chemistry at Undergraduate, Senior Undergraduate and Post-Graduate level who would choose the subject as their career. Experiment in vitro on 150 students at Undergraduate, Senior Undergraduate and Post-Graduate level showed that by using this innovative method students can save up to 3-4 mins time in the examination hall. On the basis of this, I can strongly recommend to use this innovative time economic interesting pedagogy.

\section{Acknowledgement}

The corresponding author Dr. Arijit Das, would be grateful to the SERB, DST, New Delhi, Govt. of India, for their financial assistance (Sanction no-SERB / F / 5537 / 2013-14 dated 27/11/2013 and D.O. No. SB / EMEQ - 014 / 2013).

The corresponding author would also be grateful to Prof.G.N.Mukherjee, Sir Rashbehary Ghose Professor of Chemistry, Dept. of Chemistry, Calcutta University for his appreciation and recognition in this regard.

The corresponding author give his cordial thanks to Prof.(Dr.) Debabrata Goswami, Principal, Ramthakur College, Agartala, Tripura(w), Tripura, India, for giving him this opportunity to carry out the research work in the college. He also give his cordial thanks to other faculty members of different departments in the college for providing him valuable supporting mentality. Finally, Dr.Das would be grateful to the Honble Chief Minister of the State,Mr. Manik Sarkar and Honble Ex-Higher Education Minister, Mr. Anil Sarkar for their felicitation with 'Certificate of Honour' on behalf of the State 'Tripura', Mr.Tapan Chakraborty, Education \& Higher Education Minister, Govt. of Tripura,Mr. Sekhar Datta, Chairman, tripurainfo.com and Senior Correspondent, 'The Telegraph' newspaper, Mr. Goutam Das, Editor, 'Daily Desher Katha' news Paper, Mr.Bijan Dhar, CPIM, Party Secretary of Tripura, and Mr.Jayanta Debnath, MD, Tripurainfo.com for providing their valuable sustaining mentality in this regard.

\section{References:}

[1]. Das Arijit, 'Simple Thinking Makes Chemistry Metabolic And Interesting- A Review Article', IOSR-JAC, 2014, 6(4), 08-15, doi:10.9790/5736-0640815,e-ISSN: 2278-5736.

[2]. Das Arijit, 'New Innovative Methods for Prediction of Hybridization State in a Very Short Time', IJAR, 2013, 03(07), 594

[3]. Das Arijit, Sanjeev R. and Jagannadham V., "Innovative and Time Economic Pedagogical Views in Chemical Education - A Review Article." World Journal of Chemical Education, vol. 2014, 2(3), 29-38. doi: 10.12691/wjce-2-3-1.

[4]. Pauling.L., 'J.Am.Chem.Soc.', 1931, 53(4), 1367-1400.

[5]. Mahan. B.M. and Meyers.R.J., 'International Student Edition University Chemistry', $4^{\text {th }}$ ed. , 1998, 599-603.

[6]. https://www2.chemistry.msu.edu/faculty/reusch/virttxtjml/heterocy.htm

[7]. http://www.chem.uky.edu/courses/che230/RBG/lecnotes/Bio3_orbitals.pdf

[8]. file:///C:/Users/user/Desktop/lecture451112.pdf 